\title{
Pembelajaran Blended Learning Berbasis Rotation Model terhadap Kemampuan Berpikir Kritis Matematis Siswa
}

\author{
Ulya Ulfiyati ${ }^{1}$, Himmatul Ulya ${ }^{2}$ \\ 1Pendidikan Matematika, Universitas Muria Kudus, Kudus, Indonesia; \\ *ulyaulfiyati@gmail.com \\ 2Pendidikan Matematika, Universitas Muria Kudus, Kudus, Indonesia; \\ himatululya@gmail.com
}

\begin{abstract}
Abstrak. Pembelajaran yang menyenangkan dan tidak monoton, serta adanya pandemi COVID-19, membuat guru/dosen berpikir untuk melalkukan suatu pembelajaran yang dapat mengatasi persoalan tersebut. Pembelajaran matematika dengan menggunakan model pembelajaran blended learning berbasis rotation model merupakan implikasi dari perkembangan teknologi, serta diharapkan mampu memberikan solusi dari persoalan diatas. Pencampuran pembelajaran antara pembelajaran konvensional atau tatap muka dan pembelajaran online ini, diharapkan mampu meningkatkan kemampuan berpikir kritis siswa.
\end{abstract}

Kata kunci : Blended Learning, Rotation Model, Berpikir Kritis.

Abstract. Fun and non-monotonous learning, as well as the COVID-19 pandemic, make teachers /lecturers think about learning that can solve the problem. Mathematics learning using a blended learning model based on rotation model is an implication of technological development, and is expected to provide solutions to the above problems. Mixing learning between conventional or face-to-face learning and online learning is expected to improve students' critical thinking skills.

Keywords: Blended Learning, Rotation Model, Critical Thinking.

\section{Pendahuluan}

Pada era globalisasi seperti sekarang ini, mengharuskan semua memahami teknologi, karena hampir semua kegiatan manusia membutuhkan perangkat kompleks yang dapat mempermudah aktivitasnya. Tak terkecuali pada para pendidik dan calon pendidik, mereka dituntut untuk mengaplikasikan teknologi dalam media pembelajaran. Terlebih lagi ditambah dengan adanya pandemi Covid-19, semua pembelajaran terpaksa dialihkan dirumah atau pembelajaran jarak jauh. Penggunaan media online, 
seperti Google Classroom, Edmodo, Kahoot, dan Schoology dianggap menjadi solusi untuk permasalahan saat ini dan media tersebut harus menjadi alat para pendidik untuk tetap melaksanakan pembelajaran sesuai dengan kurikulum yang berlaku agar tujuan dalam pendidikan dapat terealisasi dengan baik (Atika, Machmud \& Suwatno, 2020). Namun kadang-kadang siswa mendapat kesulitan jika hanya membaca materi dan tidak mendapat penjelasan dari guru secara langsung (Pujianingsih, 2020). Tidak hanya itu, pembelajaran secara online juga memiliki banyak varians masalah yang dapat menghambat efektivitas pembelajaran, seperti ketidaksiapan para pendidik dalam memberikan pembelajaran secara daring, keterbatasan jaringan, kurangnya kemampuan para pendidik untuk meramu dan memfasilitasi pembelajaran, serta menghabiskan kuota internet yang tidak sedikit apabila pembelajaran dilakukan menggunakan Zoom, Google meet ataupun aplikasi lainnya (Meishawati \& Putra, 2020).

Maka dari itu diperlukan sebuah inovasi yang dapat mengatasi permasalahan diatas. Istilah blended learning adalah kombinasi pembelajaran melalui media internet dan media digital dalam struktur kelas yang sudah mapan yang membutuhkan kehadiran fisik guru dan siswa (Friesen, 2014; Bakti, 2020). Selain itu, penerapan blended learning dapat membuat kepuasan siswa dalam belajar lebih tinggi daripada pembelajaran konvensional ataupun pembelajaran online saja (Kalantararrashidi $d k k$, 2015; Wulandari, Sudatha \& Simamora, 2020). Pembelajaran Blended Learning berbasis Rotation Model adalah salah satu pembelajaran yang cocok diterapkan pada saat ini, karena akan meningkatkan keterampilan Softskill bagi peserta didik (Maulida, 2020). Menurut Wulandari \& Almenda, 2020 dalam Gusnawan \& Priatna, 2020 Pembelajaran kombinasi ini dapat mengembangkan dan memperluas proses pembelajaran dengan memberikan variasi tentang pembelajaran lingkungan dan materi pembelajarannya. Pembelajaran yang dapat dikombinasi ini salah satunya dilakukan dengan online, offline, mendengarkan audio, video, membaca materi untuk peningkatan kemampuan diri, dan berkomunikasi melalui aplikasi seperti Skype, Zoom meeting, dan google meet.

Menurut penelitian Gusmawan \& Priatna, 2020 pembelajaran blended learning juga dapat meningkatkan kemampuan berpikir kritis secara nyata. Mengingat kemampuan berpikir kritis peserta didik di Indonesia masih rendah. Hal ini sesuai dengan penelitian (Rahmawati, et. All, 2016) bahwa kemampuan berpikir kritis siswa tingkat menegah masih rendah dan juga kemampuan berpikir kritis ini tidak merupakan kemampuan yang melekat pada manusia sejak lahir, namun bisa dikembangkan dan dimaksimalkan. 
Dalam hal ini, peneliti tertarik untuk mengkaji permasalahan untuk meningkatkan kemampuan berpikir kritis dengan menggunakan pembelajaran blended learning berbasis rotation model.

\section{Metode}

Penelitian ini dilakukan melalui studi pustaka atau literatur review. Penelitian studi pustaka atau literatur review adalah penelitian yang dilakukan dengan mengkaji mengenai konsep dan teori yang digunakan berdasarkan literatur yang tersedia, yang diantaranya artikel-artikel yang dipublikasikan dalam jurnal ilmiah yang berisi teori-teori yang revelan dengan masalah-masalah penelitian. Yang menjadi sumber data dalam penelitian ini adalah jurnal-jurnal yang terdapat dalam beberapa media elektronik seperti digital library, internet, dan dengan melalui google scholar, kata kunci yang digunakan dalam penelusuran pada jurnal dan buku yang relevan dalam penelitian ini yaitu "Blended Learning Berbasis Rotation Model" dan "Kemampuan Berpikir Kritis Matematis".

\section{Hasil dan Pembahasan}

\section{Konsep Blended Learning}

Konsep blended learning pada penelitian Amin (2017) pada (Mutmainnah, Suswandari 2020) adalah pencampuran model pembelajaran konvensional atau pembelajaran tatap muka dengan pembelajaran online. Peserta didik diharapkan mampu menemukan cara belajar yang tepat untuk dirinya dan selalu aktif dalam pembelajaran. Guru hanya sebagai moderator, fasilitator dan teman yang membuat situasi kondusif pada saat pembelajaran berlangsung. Tujuan utama darai pembelajaran blended learning ini juga untuk memperkuat model pembelajaran konvensional melaui teknologi pendidikan yang sedang berkembang. Selain itu juga hasil pada jurnal dapat disimpulkan bahwa rata-rata hasil penelitian ini, memberikan pengruh terhadap hasil belajar peserta didik.

Menurut Atika, Machmud, Suwanto (2020), pembelajaran blended learning mampu meningkatkan hasil belajar peserta didik sama atau malah lebih tinggi dari pembelajaran yang sepenuhnya tatap muka, dan pembelajaran yang sepenuhnya online. Hal itu cukup membuat guru/dosen menggunakan pembelajaran blended learning karena dianggap dapat menciptakan hasil belajar yang memuaskan meskipun sedang dalam keadaan pendemi COVID-19. Meskipun terdapat beberapa pertentangan dari beberapa kalangan terutama orang tua peserta didik, yang mengeluhkan dampak negatif dari penggunaan gadget secara berlebih. Tetapi tidak dapat dipungkiri bahwa pembelajara dengan metode blended learning secara signifikan dapat meningkatkan hasil belajar dan prestasi peserta didik.

\section{Definisi blended learning berbasis Rotation model}

Copyright (C) 2021

Buana Matematika :

Jurnal Ilmiah Matematika dan Pendidikan Matematika 
Rotation Model adalah sebuah program yang mengarahkan peserta didik untuk berotasi dalam sebuah jadwal yang telah ditetapkan oleh guru (yang minimal satu pembelajaran dilakukan secara online). Kegiatan rotasi ini dapat berupa kelas dengan kelas, kelas dan lab komputer, ataupun kelas dengan luar sekolah, disesuaikan dengan kebutuhan individu dan pembelajaran (Gunawan, Priatna, 2020). Hal ini juga serupa dengan penelitian Dakhi, $d k k 2020$ bahwa "The Rotation Model includs four sub-models, namely: Station-Totation Model, LabRotation Model, Flipped-Rotation Model, and Individual-Rotation Model".

Hasil penelitian yang telah dilakukan oleh Munzandi, 2018, terdapat perbedaan motivasi belajar siswa antara kelas yang menggunakan metode pembelajaran blended learning berbasis rotation model dengan kelas yang tidak menggunkaan metode pembelajaran. Hal ini diperkuat dengan banyaknya kelebihan lain dari pembelajaran blended learning ini, diantaranya hemat waktu, pembelajaran lebih efektif dan efisien, mempermudah peserta didik mengakses materi pembelajaran, dan peserta didik dapat melakukan diskusi dengan mudah diluar jam tatap muka. Sebagaimana telah dikemukakan pada landasan teori bahwa model blended learning merupkan pembelajaran yang berpusat pada siswa, sehingga siswa lebih banyak terlibat secara aktif pada pembelajaran.

\section{Kemampuan Berpikir Kritis.}

Tantangan abad ke 21 adalah bagaimana mengembangkan keterampilan peserta didik terutama keterampilan berpikir kritis. Begitu pentingnya kemampuan berpikir kritis ini untuk proses berpikir siswa untuk memutuskan dan menarik kesimpulan yang dapat dipertanggungjawabkan. Hal ini sesuai dengan penelitian Hadisaputra, dkk 2020 bahwa "The skills that learners need to trained in order to meet the 21st century challenges in the ability to think critically".

Pada awalnya perkembangannya terjadi perdebatan diantara para ahli mengenai kemampuan berpikir kritis, apakah berpikir kritis adalah suatu kemampuan yang menyangkut denagn motivasi, dan karakter bawaan atau gen. Namun penelitian yang dilakukan Rahmawati (2016) menyimpulkan bahwa indikasi rendahnya kemmapuan berpikir kritis siswa dapat diatasi dengan memberikn solusi latihan pembelajaran yang menekankan pada kemampuan pemecahan masalah. Dengan garis besar, dapat disimpulakn bahwa berpikir kritis merupakan sebuah kemampuan kognitif yang meliputi dua aspek yakni berpikir logis dan pemecahan masalah.

Beberapa hal berikut diatas sesuai dengan penelitian Pujiasih (2020), bahwa pembelajaran online untuk membangun dan mempersiapkan generasi emas tahun 2045 sangat diperlukan variasi kegiatan pembelajaran, serta adanya pembatasan jarak akibat adanya pandemi COVID-19 juga menjadi suatu keaharusan diterapkannya pembelajaran secara online. Disamping itu, pembelajaran konvensional tetap harus dilakukan setalah meredanya pamdemi COVID-19, kaena 
pembelajaran konvensional atau tatap muka membantu peserta didik mengenal lingkungannya dan bersosialisasi dengan lingkungan sekitar.

\section{Simpulan}

Berdasarkan hasil analisis pada bagian pembahasan, penulis menyimpulkan bahwa perlu diadakannya sebuah variasi pembelajaran yang dapat mengatasi permasalahan terlalu monotonnya suatu pembelajran, serta adanya pandemi COVID-19. Pemilihan strategi bersifat fleksibel yang mana hal ini merupakan implikasi dari pemilihan submodel dari pembelajaran blended learning, serta diharapkan mampu menjadi solusi dari permasalahan tersebut. Menurut penelitian penulis dengan metode literature review penggunaan pembelajaran blended learning berbasis rotation model cocok duterapkan pada sekolah yang telah memiliki fasilitas yang memadai.

\section{Daftar Pustaka}

Ayu, I. G., Manik, A., \& Simamora, A. H. (2020). Pengembangan Pembelajaran Blended Pada Mata Kuliah Ahara Yoga Semester II di IHDN Denpasar. 8, 1-15.

Raya, F., \& Kusuma, F. (2020). Kajian pembelajaran blended learning. 1-10.

Muthmainnah, A., \& Suswandari, M. (2020). Implementasi Station Rotation Blended Learning tehadap Motivasi Belajar dan Pendidikan Karakter Peserta Didik. International Journal of Public Devotion, 3(2), 59-64.

Atika, A., Machmud, A., \& Suwatno, S. (2020). Pendekatan Meta-Analisis: Blended Learning terhadap Hasil Belajar DI Era Covid-19. Jurnal Basicedu, 4(4), 919-926. https://doi.org/10.31004/basicedu.v4i4.488

Munzadi, M. (2018). Pengaruh Blended Learning Berbasis Rotation Model Terhadap Motivasi Dan Hasil Belajar Geografi Siswa Ma Matholiul Anwar Lamongan. Jurnal Pendidikan Geografi Undiksha, 6(3), 125-132. https://doi.org/10.23887/jjpg.v6i3.20699

Hadisaputra, S., Ihsan, M. S., Gunawan, \& Ramdani, A. (2020). The development of chemistry learning devices based blended learning model to promote students' critical thinking skills. Journal of Physics: Conference Series, 1521(4). https://doi.org/10.1088/1742-6596/1521/4/042083

Made, D., \& Putra, D. (2020). Station Rotation Type Blended Learning Model Against Critical Thinking Ability of Fourth Grade Students. 4, 516-523.

Copyright $@ 2021$

Buana Matematika :

Jurnal Ilmiah Matematika dan Pendidikan Matematika 
Jurnal Ilmiah Matematika dan Pendidikan Matematika

Vol. 11 No. 1 (2021)

Maulida, U. (2020). Konsep Blended Learning Berbasis Edmodo Di Era New

Normal. Dirasah, 2, 121-136.

Dakhi, O., Jama, J., Irfan, D., Ambiyar, \& Ishak. (2020). Blended Learning: a 21St Century Learning Model At College. International Journal of Multi Science, 1(2), 17-23.

Pujiasih, E. (2020). Membangun Generasi Emas Dengan Variasi Pembelajaran Online Di Masa Pandemi Covid-19. Ideguru: Jurnal Karya Ilmiah Guru, 5(1), 42-48. https://doi.org/10.51169/ideguru.v5i1.136

Puspendik (Pusat Penilaian Pendidikan Badan Penelitian dan Pengembangan Kementrian Pendidikan dan Kebudayaan). 2012. Kemampuan Matematika sisw SMP Indonesia Menurut Benchmark Internasional TIMSS 2011. Jakarta:PUSPENDIK.

Gusmawan, D. M., \& Priatna, N. (2020). Pengembangan Bahan Ajar Model Pembelajaran Blended Learning Berbantuan Geogebra untuk Meningkatkan Kemampuan Berpikir Kritis Matematis Siswa SMA. Edsence: Jurnal Pendidikan Multimedia, 2(2), 93-100. https://doi.org/10.17509/edsence.v2i2.22871

Rahmawati, L., et al., 2016. Analisis Keterampilan Berpikir Kritis Siswa SMP pada Materi Gaya dan Penerapannya, Prosiding Seminr Nasional Pendidikan IPA Pascasarjana UM (hlm 1112-1119), Malang: Lemlit UM. 